ks. Wojciech Mleczko CR

Stryszawa

\title{
O. Hieronim Kajsiewicz CR (1812-1873): troska o duchowość troską o dobro społeczności. Sprawozdanie z IV Międzynarodowego Sympozjum z cyklu Duchowość Klasztorów Polskich: Przekaz i Komunikacja (Kraków, 28 lutego 2012)
}

W roku 2012 przypada 200. rocznica urodzin o. Hieronima Kajsiewicza CR, współzałożyciela Zgromadzenia Zmartwychwstania Pańskiego, wybitnego kapłana, kaznodziei i patrioty.Z tej okazji Polska Prowincja Zmartwychwstańców wraz z Katedrą Duchowości Mediów i Relacji Społecznych Wydziału Nauk Społecznych Uniwersytetu Papieskiego Jana Pawła II w Krakowie zorganizowała międzynarodowe sympozjum naukowe pt. O. Hieronim Kajsiewicz CR (1812-1873): troska o duchowość troską o dobro społeczności. Miało ono miejsce 28 lutego 2012 roku w Centrum Resurrectionis w Krakowie (ul. Ks. S. Pawlickiego 1). Była to już czwarta konferencja z cyklu Duchowość Klasztorów Polskich: Przekaz i Komunikacja. Przypomnijmy, że poprzednia za swojego bohatera miała także wybitnego zmartwychwstańca: Sługę Bożego o. Piotra Semenenkę (1814-1886). Podobnie jak w roku ubiegłym, i tym razem za bezpośrednią organizację byli odpowiedzialni ks. prof. dr hab. Wojciech Misztal, prorektor UPJPII oraz ks. mgr. lic Wojciech Mleczko CR z Międzynarodowej Komisji Studiów Zmartwychwstańczych.

Sympozjum rozpoczęto uroczystą Eucharystią pod przewodnictwem biskupa polowego Wojska Polskiego J. E. Józefa Guzdka. W czasie kazania ksiądz biskup, autor rozprawy doktorskiej o bohaterze sympozjum, powie- 
dział: „Miałem to wielkie szczęście głębiej poznać dorobek homiletyczny ks. Hieronima Kajsiewicza, a nawet zaprzyjaźnić się ze słynnym kaznodzieją. Urzekł mnie życiorys niezwykłego człowieka, który dał się uwieść Chrystusowi. Pomimo czasu zwątpienia, a nawet odejścia od Boga, uznał Chrystusa za swoje jedyne Dobro i służył Mu jako kapłan, współzałożyciel Zgromadzenia Księży Zmartwychwstańców, a nade wszystko gorliwy sługa i głosiciel słowa Bożego".

Po przejściu do Sali Kapitulnej formalnego otwarcia sesji naukowej dokonał o. Wiesław Śpiewak CR, przełożony Polskiej Prowincji Zmartwychwstańców. Przywitał także słuchaczy, wśród których znajdowały się siostry zmartwychwstanki, siostry niepokalanki, siostry urszulanki szare, przedstawiciele laikatu oraz wielu zmartwychwstańców. Razem około stu osób. W czasie sesji przedpołudniowej (której przewodniczył ks. prof. dr hab. Stefan Koperek CR) oraz popołudniowej (przewodniczący: ks. prof. dr hab. Wojciech Misztal), wygłoszono dziesięć referatów, których autorami byli profesorowie i pracownicy naukowi z Uniwersytetu Papieskiego Jana Pawła II w Krakowie, Uniwersytetu Gdańskiego, Uniwersytetu Jagiellońskiego oraz dwaj zmartwychwstańcy z Ukrainy i z Polski.

Oto relacja z kolejnych wystąpień:

- Ks. prof. dr hab. Wojciech Misztal (UPJPII) w referacie Potrzeba przyjęcia obecności Boga w życiu osobistym i społecznym w świetle „Rozmyślań o męce Chrystusa Pana" ks. Hieronima Kajsiewicza CR, analizując tytułowe i cenione rozmyślania, stwierdził: „ks. Kajsiewicz ukazuje, iż dla człowieka zjednoczenie z Bogiem jest niezbędne, pozytywnie znaczące. Dotyczy to tak życia osobistego, jak i społecznego. [...] Podejście ks. Kajsiewicza do zagadnienia otwarcia się na obecność Boga posiada charakter pedagogiczny, terapeutyczny, profilaktyczny. Ukazuje przydatność chrześcijaństwa, jego cenną rolę tak w życiu osobistym, jak i społecznym".

- Problem Wspótczesnych implikacji wychowawczych nauczania ks. Hieronima Kajsiewicza $w$ formacji podjął w swoim wystąpieniu ks. prof. dr hab. Janusz Mastalski (UPJPII). Z dużej spuścizny literackiej ks. Kajsiewicza prelegentowi udało się wydobyć kilka bardzo konkretnych wskazań formacyjnych, które nie tylko nie straciły na aktualności, ale jeszcze wyraźniej brzmią w dzisiejszych czasach. Według ks. Kajsiewicza celem wychowania jest człowiek „z wyobrażeniami i zasadami chrześcijańskimi” oraz „harmonia we współczesnej rodzinie chrześcijańskiej”. Natomiast wśród współczesnych 
implikacji wychowawczych nauczania o. Kajsiewicza prelegent wymienił: „ciszę, która umożliwia medytację i modlitwę”, ,ogromne znaczenie modlitwy w życiu człowieka”, ,nacisk na kształtowanie sumienia”, , wytrwałość w pracy nad sobą". Wychowanie powinno: a) odbywać się w oparciu o spójny system wartości; b) mieć u podstaw wiarę; c) pamiętać o patriotyzmie jako niezwykle istotnym elemencie; d) bazować na etyce.

- Pani dr hab. Izabela Kępka z Uniwersytetu Gdańskiego podejmując temat Świat wartości zawarty w przepowiadaniu ks. Hieronima Kajsiewicza $C R$ opisany językiem, ukazała piękno i bogactwo języka, którym posługiwał się o. Kajsiewicz w swoich mowach i pismach. Ze znawstwem filologa wprowadziła słuchaczy w „zabiegi językowe”, „sposoby wartościowania”, „strukturę tekstu”, ,motywy tematyczne”, ,waloryzację pojęć”, , ,językowy element wartościujący”, ,quasi-definicje”, „konstrukcje składniowe”, „środki artystyczne”, metaforyczne obrazy”, „zabiegi stylistyczne”, „leksykę wartościującą", wykazując tym samym, że ks. Hieronim Kajsiewicz był świadomym użytkownikiem języka. Umiał wykorzystać jego zasoby w przekazie duchowości chrześcijańskiej.

- Święci w dziejach Kościoła i Ojczyzny w kazaniach ks. Hieronima Kajsiewicza to temat wystąpienia ks. dr. hab.Janusza Królikowskiego, prof. UPJPI. Referent dokonał przeglądu spuścizny kaznodziejskiej ks. Kajsiewicza (,jednego z najznamienitszych polskich kaznodziejów XIX wieku") i zwrócił uwagę na „jeden z ważnych tematów, który pojawia się w kazaniach H. Kajsiewicza, a mianowicie rolę świętych w dziejach Kościoła i Ojczyzny". Wśród świętych zostali wymienieni: św. Jacek, św. Jozafat Kuncewicz i św. Andrzej Bobola, św. Jan Kanty. Ks. Kajsiewicz ukazywał świętych jako „żyjących pośmiertnie, i to żyjących jeszcze intensywniej niż w czasie ziemskiej wędrówki" oraz zwracał uwagę, że zasadniczym aspektem oddawania czci świętym jest ich naśladowanie.

- Ks. dr hab. Wojciech Zyzak, prof. UPJPII zbadał nauczanie o. Kajsiewicza pod kątem laikatu. W referacie pt. Laikat i jego rola w odnowie moralnej i religijnej narodu w nauczaniu o. Hieronima Kajsiewicza ukazał, jak doniosłą rolę przypisywał o. Kajsiewicz ludziom świeckim. Podstawą tytułowej odnowy jest przekonanie, że „los narodu zależy od wierności Bogu i Kościołowi. W tym względzie Kajsiewicz pokazywał, że ludzie świeccy zawsze byli gotowi oddać życie za Boga i Kościół. Ich przykład miał umacniać Polaków w kraju i na emigracji, by pobożnie trwali przy Bogu, dbali o moralność 
i zachowanie nienaruszonych więzi rodzinnych, a także po chrześcijańsku wypełniali swoje zadania pośród świata".

- Wystąpienie ks. dr. hab. Henryka Sławińskiego (UPJPII) zatytułowane Aktualność homiletycznych wskazań o. Hieronima Kajsiewicza CR stało się okazją do ukazania ponadczasowości teoretycznych i praktycznych wskazówek ks. Kajsiewicza w temacie sztuki kaznodziejskiej. Dzisiejsi głosiciele słowa Bożego mogliby wiele się nauczyć od ,kaznodziei, jakiego w Polsce od czasów Skargi nie było". Na przykład chrystocentryzmu, bazowania na Piśmie Świętym czy formalnych aspektów wystąpień publicznych (kompozycja, styl, język, gestykulacja, memoryzacja).

- Ks. dr Kazimierz Mikucki CR (WSD Lwów) ukazał Świat wartości ojca Hieronima Kajsiewicza na podstawiejego listów z podróży do Ameryki. Wartości, jakimi był najbardziej zainteresowany o. Kajsiewicz, to Bóg i ludzie, a ci ostatni w aspekcie ich obyczajów i stosunku do Boga. Warto wspomnieć, że omawiane listy są pełne barwnych opisów Kanady i USA z drugiej połowy XIX wieku.

- Pan dr Henryk Głębocki z Uniwersytetu Jagiellońskiego na podstawie nieznanych dotąd szerzej materiałów przedstawił kontakty zmartwychwstańców z kontrowersyjną postacią hrabiego Adama Gurowskiego (Kajsiewicz, zmartwychwstańcy i hrabia Adam Gurowski [1805-1866]). Przypomniał, że przez pewien czas był on jednym z najbliższych przyjaciół Bogdana Jańskiego oraz nauczycielem Piotra Semenenki. Miał styczność także z H. Kajsiewiczem. Sytuacja uległa jednak diametralnej zmianie po tzw. apostazji narodowej Gurowskiego i przyjęciu przez niego koncepcji panslawistycznej z Rosją na czele.

- W referacie ks. dr. Marcina Godawy (UPJPII) pt. Indywidualne doświadczenie bohatera romantycznego wobec Boga i Kościoła w powieści poetyckiej „Nunc dimittis, Domine” Hieronima Kajsiewicza zostało przeanalizowane „romantyczne postrzeganie człowieka jako istoty obdarzonej wielkim dynamizmem duchowym, która poszukuje realizacji w konkretnym czynie". Omawiana powieść stanowiła równocześnie „próbę syntezy mocno indywidualnej duchowości człowieka [...] z nauką katolicką".

- Zamykające konferencję wystąpienie ks. dr. Kazimierza Wójtowicza CR z Komisji Studiów Zmartwychwstańczych zatytułowane Hieronima Kajsiewicza początek drogi do ołtarza (okres paryski) było próbą przybliżenia słuchaczom zapomnianych i nieznanych szczegóły z pierwszego okre- 
su formacji ku kapłaństwu, który Kajsiewicz spędził w Paryżu (nowicjat w Domku Jańskiego i studia w Collège Stanislas).

W czasie sympozjum przewidziano także czas na dopowiedzenia i dyskusję, które nadały barw konferencji. Szczególne zasługi w tej materii miał dr M. M. Tytko z Uniwersytetu Jagiellońskiego. Z kolei w przerwach można było zwiedzić kompleks Centrum Resurrectionis, w tym unikatową kaplicę obrządku wschodniego oraz muzeum zmartwychwstańców, a przede wszystkim specjalnie przygotowaną wystawę nt. o. Hieronima Kajsiewicza CR. Konferencja została zakończona uroczystymi nieszporami w kościele seminaryjnym pw. „Emaus”, którym przewodniczył Ojciec Prowincjał Wiesław Śpiewak CR.

Na koniec należy dodać, iż na relacjonowanym sympozjum zaprezentowano i skonfrontowano wyniki badań zawarte w uprzednio wydrukowanej przez Wydawnictwo Naukowe UPJPII publikacji: O. Hieronim Kajsiewicz CR (1812-1873): troska o duchowość troska o dobro społeczności, red. W. Misztal i W. Mleczko, Kraków 2012, ss. 250.

Kolejną konferencję z cyklu Duchowość Klasztorów Polskich: Przekaz i Komunikacja zaplanowano na 19 maja 2012 roku. Zostanie poświęcona św. Urszuli Ledóchowskiej i Urszulankom Serca Jezusa Konającego, a będzie miała miejsce w Łodzi. 
